\title{
Soy Isolate Protein Formula: the Usage beyond Allergy Indication
}

\author{
Zakiudin Munasir $^{1}$, Rini Sekartini ${ }^{1}$ \\ 1. Department of Pediatric, Faculty of Medicine, Universitas Indonesia, CIpto Mangunkusumo \\ Hospital, Jakarta, Indonesia
}

Received 10 April 2020

Accepted 28 April 2020

Link to DOI:

10.25220/WNJ.V04.S1.0005

Journal Website:

www.worldnutrijournal.org

\section{Introduction}

The usage of soy isolate protein formula for infants was recommended by Indonesian Pediatrics Association (IDAI) through the recommendation of Cow's Milk Protein Allergy (CMPA) management in 2014. Soy Infant Formula (SIF) has been being used for Infants with Cow's Milk Protein Allergy (CMPA) as well as for several other related medical indications such as post diarrhea lactose intolerance, galactosemia and primary lactase deficiency. ${ }^{1}$ At early stage of soy formula, it had several deficiencies, infant acceptability, growth, and incomparable with milk-base formula. Current SIF is made from soy protein isolate that contain 2.2-2.6 $\mathrm{g}$ of protein per 100 calories, it is higher than milkbased formula and both showed same growth and development in infants. ${ }^{2}$ It contains different fibers, phytate, digestibility, protease inhibitor and proteins. SIF is easily digestible and contain high amino acid content fortified with L-methionine, L-

\footnotetext{
Corresponding author:

Prof. Dr. dr. Zaikudin Munasir, $\operatorname{SpA}(K)$

Department of Pediatric, Faculty of Medicine, Cipto

Mangunkusumo Hospital, Jakarta, Indonesia

E-mail address: zakiudin.munasir@gmail.com
}

carnitine and taurine. High content of phytate is overcome with zinc and iron fortification as well as increased levels of calcium and phosphor. ${ }^{3}$ American Academy of Pediatrics recommends isolated soy protein-based formulas as a safe and effective alternative for providing appropriate nutrition for normal growth and development for term infants whose nutritional needs are not being met from maternal breast milk or cow's milk-based formulas. $^{3,4}$

Soy isolate protein formula is commonly used as management of CMPA besides extensively hydrolyzed formula (eHF) and amino acid formula (AAF). Each formula possesses its own indications, advantages and disadvantages. The AAP (American Academy of Pediatrics) and the ESPGHAN (European Society for Pediatrics Gastroenterology Hepatology and Nutrition) recommended that SIF is a rational option and can be justified in CMPA children. ${ }^{3,4}$ Based on the Indonesia Pediatrics Association (IDAI) guidelines, the choice of formula for CMPA is restricted between eHF, AAF or SIF. According to the guideline, SIF is an alternative formula for infant with low to moderate allergy symptoms when there is an issue with affordability or availability of $\mathrm{eHF}^{2}$

Soy isolate protein formula administration is often debated because although it does not contain cow's milk protein, $10-14 \%$ children with CMPA 
are also allergic to soy and SIF adverse reaction such as enterocolitis occurred in $30-64 \%$ CMPA children. $5,6,7$ This condition is a challenge for clinician and may be taken into consideration. Some researchers also debated about its conflicting evidence about the risks and benefits of phytoestrogens contained in SIF. ${ }^{8}$

The consumption of SIF is a rational option when mature infants are not able to get breastfeeding and intolerance to cow's milk is present. Another indication of SIF is galactosemia, hereditary lactase deficiency and conditions that require vegetarian diet and to reduce colic complaints. However, the benefits of SIF beyond allergies are yet widely known. Therefore, in this review, the Soy Infant Formula safety issues and its benefits beyond allergies are discussed.

\section{Soy infant formula usage in Indonesia}

The utilization rates of Soya Infant Formula (SIF) have been repeatedly found to be higher than expected compared to the reported incidence of over mentioned indications for SIF use. It was reported that SIF was used nearly $20 \%$ in Canada (year $2005)^{9}$ and $25 \%$ in the USA (year 2008). ${ }^{6}$ A recent evaluation of the consumption of different types of feeding among a nationally representative sample of 1,864 infants aged $0-12$ months in the USA reported that among $81 \%$ of infants who were fed formula or regular milk and $12 \%$ consumed SIF. ${ }^{10}$ However, SIF is only used for management of Cow's Milk Protein Allergy in Indonesia. ${ }^{2}$ This consensus is based on the $\mathrm{AAP}^{6}$ and the ESPGHAN ${ }^{4}$ which stated few indications for the use of SIF in infant. Several studies have shown that presently available SIF can allow for the normal growth and development of full-term infants. Moreover, full-term infants, galactosemia, and hereditary lactase deficiency are the only clinical conditions for which SIF are considered the best solution for feeding infants. Finally, they can be used when a vegan diet is preferred. Other clinical conditions that were initially considered possible indications for SIF use are presently preferentially treated with different nutritional approaches. ${ }^{11}$ It is also the consideration for the use of SIF in Indonesia. ${ }^{2}$

According to the Indonesian Pediatrics Association (IDAI) Guidelines, the management of cow's milk protein allergy (CMPA) consists of diagnosis and therapy in children with CMPA. Diagnosis can be performed in children by dietary elimination of cow's milk protein, standardized oral challenge test, IgE specific test, skin test and patch test. Even though the gold standard for diagnosing CMPA is through a standardized oral test, many clinicians still diagnose CMPA based on symptoms. The therapy itself lies within the algorithm of avoiding the allergen which is cow's milk protein. For breastfed infant, it is recommended for the mother to avoid the consumption of all cow's milk protein and its derivatives. In IDAI guidelines, the therapy for CMPA is extensively hydrolyzed protein formula's (eHF) although this formula is more expensive and less palatable than SIF since some cases are also suffer from soy protein allergy. It is stated in the IDAI Guidelines, however, if eHF is not available or too expensive for patients, soy infant formula (SIF) may be used but patients need to be educated with SIF adverse effects. ${ }^{2}$

The World Health Organization (WHO) also mentioned soy infant formula in CODEX STAN 721981 of Standard for Infant Formula and Formulas for Special Medical Purposes Intended for Infants. The minimum value of protein for soy infant formula based on soy protein isolate is $2.25 \mathrm{~g} / 100$ kcal $(0.5 \mathrm{~g} / 100 \mathrm{~kJ})$ based on CODEX. The Indonesian National Food and Drug Agency (Badan Pengawas Obat dan Makanan/BPOM) regulates soy infant formula and its minimum value of protein is in line with CODEX, which is $2.25 \mathrm{~g} / 100 \mathrm{kcal}$ and maximum of $3 \mathrm{~g} / 100 \mathrm{kcal}$. This concludes that soy infant formula has met the standardized minimum for nutrients for infants and is regulated by BPOM though the intended use of SIF is not mentioned in the regulation. ${ }^{12,13}$.

\section{Benefits and challenges of soy infant formula}

The efficacy of SIF for CMPA management is often debated because although it does not contain cow's milk protein, some children with CMPA are also allergic to soy. Some SIF adverse effects of SIF such as enterocolitis are also a consideration. Despite the low prevalence of soy allergy there is still a possibility of anaphylaxis risk in SIF. ${ }^{5}$ The AAP, the EPSGHAN and IDAI recommended SIF as a rational choice and can be justified in CMPA 
children. ${ }^{2,4,6}$ For breastfed infants, eliminating of all cow's milk protein and other protein sources such as soy is required. For formula-fed infants, current options include specific allergen avoidance and the use of eHF and AAF. Their efficacy for CMPA is approximately $90 \%$ compared to other management such as SIF. However, the availability and the taste of the formula might be an issue for compliance, that is why SIF is considered as an alternative. ${ }^{14}$

Medical indication of SIF is actually limited to galactosemia and primary lactase deficiency which are very rare conditions. There is no indication to recommend the use of SIF in the prevention of CMPA, treatment of colic or as a supplement to breastfeeding. Incidence of allergy to soy or cow milk proteins has been reported to be comparable. In addition to the limited medical indications, there is also some economic, religious and philosophical reasons to advice soy although eHF has shown evidence to be more effective. SIF is substantially cheaper than eHF and it is safe and does not financially burden patients. Some eHFs are derived from pork pancreas so religious decision might affect patient decision. In this situation, SIF is a preferable option than other formulas, especially if the patient requests for vegan diet. ${ }^{15}$

The safety of SIF, however, is another debate. Although reports have shown infants with SIF showed normal development and growth, some have concerns with potential adverse effect of phytochemicals in SIF such as phyto-estrogens. SIF showed no significant difference when compared to cow's milk formula and breast milk in parameters such as body length, weight and head circumference. $^{3,16}$ Despite SIF's high level of aluminum content, it has been shown that it is not a safety issue since the value is within the limit allowed by WHO and BPOM. ${ }^{12,13}$ Disorder of sexual development, hypothyroidism with euthyroid conditions and disorder of immune function have not been proven. ${ }^{3,6}$

SIF administration and its safety issues on sexual development and hormonal disorders are often questioned due to isoflavones content which have active metabolites in blood. Isoflavones are phyto-estrogens that hypothetically may cause disruption of sexual development and disorders of hormonal development in infants. Many studies in animals and mice showed that soy affected sexual development but it turned out that humans have a different metabolism of isoflavones in blood. Isoflavone metabolites are 20-150 times higher in mice than in human. The study concluded that the soy interference with sexual development and hormonal should not be drawn from animal studies. ${ }^{5}$ The isoflavone content in soy isolate formula is not significant to cause unfavorable side effect. ${ }^{6}$

The administration of SIF is safe and cost effective for CMPA children if the children cannot tolerate eHF. Many studies showed contradicting results in regards of its safety but all of these were not proven and inconclusive. $3,5,6,15$

\section{SIF beyond allergies}

Based on the description above, numerous studies have documented normal growth and development in term neonates fed with SIF. The average energy intake in infants receiving soy protein-based formulas is equivalent to those achieved with cow milk formula. Serum albumin concentration, as a marker of nutritional adequacy is normal in infants with SIF. ${ }^{6}$ Mineral content in SIF has been adapted and modern SIF using hydrolyzed phytate does not affect growth and bone mineralization compared to cow's milk formula and does not induce risk of malnutrition. ${ }^{16}$

On the other hand, SIF is not recommended for preterm infants. Serum phosphorus concentrations are lower, and alkaline phosphatase concentrations are higher in preterm infants fed with SIF than they are in preterm infants fed cow milkbased formula. As anticipated from these observations, the degree of osteopenia is increased in infants with low birth weight receiving SIF. The cow milk protein-based formulas designed for preterm infants are clearly superior to soy proteinbased formula for preterm infants. ${ }^{6}$ The AAP also concluded that the aluminium in SIF is not a safety issue, except in preterm infants and infants with renal failure, because their daily of aluminium intake is lower than $1 \mathrm{mg}$ per day thus SIF contains $<0.5$ $\mathrm{mg} / \mathrm{kg}$ /day aluminium in infants consuming SIF 200 $\mathrm{mL} / \mathrm{kg} /$ day. ${ }^{2,6,16}$ Opportunity of using SIF in the recovery of acute infantile diarrhea complicated by secondary or transient lactase deficiency has been addressed in many studies. The duration of diarrhea has been reported to be shorter in infants receiving 
SIF and the duration of liquid stools may also be reduced with additional soy polysaccharide fiber compared to human milk and cow-based formula. However, after rehydration, most infants can be managed successfully with continued breastfeeding or standard cow milk or SIF. Because primary or congenital lactase deficiency is rare, very few individuals would require a total restriction of lactose. Lactose intolerance is more likely to be dose dependent. Thus, the use of soy protein-based lactose-free formulas for this indication should be restricted. ${ }^{6,17}$

The most common reason for using SIF by care providers is to relief of perceived formula intolerance (spitting, vomiting, and fussiness) or symptoms of colic since this can be a symptom of CMPA also. ${ }^{17}$ Effect of partially hydrolysed formula have not concluded in this particular area. ${ }^{18}$ Colicky discomfort is often described by the parents during the first 3 months of age in 10-20\% infants. Parents frequently seek relief by changing infant formula, although many factors can cause this behaviour. The benefit of SIF to calm colic is not significant, it might be attributed to sucrose and fiber content. Education and Communication to parents are key in addition to switching to SIF because colic-related behaviour will pass spontaneously between 4 and 6 months of age. ${ }^{6}$

\section{Optimizing growth and development with SIF}

Isolated soy protein-based formulas currently on the market are all free of cow milk protein and lactose and provide $67 \mathrm{kcal} / \mathrm{dL}$. All formulas are ironfortified and meet the vitamin, mineral, and electrolyte specifications addressed in the 2004 guidelines from the AAP for feeding term infants and established by the US Food and Drug Administration. In Indonesia, all SIF are subject to the BPOM regulation ${ }^{13}$. The protein in SIF is a soy isolate supplemented with L-methionine, Lcarnitine, and taurine to provide a protein content of 2.45 to $2.8 \mathrm{~g}$ per $100 \mathrm{kcal}$ or 1.65 to $1.9 \mathrm{~g} / \mathrm{dL}$. The fat content of soy protein-based formulas is derived primarily from vegetable oils. The quantity of specific fats varies by manufacturer and is usually similar to those in the manufacturer's corresponding cow milk-based formula. The fat content ranges from 5.02 to $5.46 \mathrm{~g}$ per $100 \mathrm{kcal}$ or 3.4 to $3.6 \mathrm{~g} / \mathrm{dL}$.
The oils used include soy, palm, sunflower, olein, safflower, and coconut. Docosahexaenoic and arachidonic acids now are added routinely. ${ }^{2,6}$

In formulas, carbohydrate sources are corn maltodextrin, corn syrup solids, and sucrose, with content ranging from 10.26 to $10.95 \mathrm{~g}$ per $100 \mathrm{kcal}$ or 6.9 to $7.4 \mathrm{~g} / \mathrm{dL}$. Until 1980, mineral absorption from soy formulas was bad since as mentioned above SIF contains $1.5 \%$ phytate and $30 \%$ phosphorus is phytate bound. With the current formulations, bone mineralization, serum concentrations of calcium and phosphorus, and alkaline phosphatase concentrations in term infants through 12 months of age are equivalent to those observed in infants fed with cow milk-based formulas. Because soy phytates and fiber oligosaccharides also bind iron and zinc, all soybased formulas are fortified with iron and zinc. ${ }^{6,16}$

Isoflavones are commonly found in legumes, with the highest amount found in soybeans. Concerns have been raised in relation to phytoestrogens/isoflavones include their potential negative effects on sexual development and reproduction, neurobehavioral development, immune function, and thyroid function. But as mentioned above, the studies are inconclusive and has not been proven. ${ }^{3,8}$

High content of aluminium in soy-based formulas is debated since the first SIF was established. Although the aluminium content of human milk is 4 to $65 \mathrm{ng} / \mathrm{mL}$, that of soy proteinbased formula is 600 to $1300 \mathrm{ng} / \mathrm{mL}$. The toxicity of aluminium is traced to increased deposition in bone and in the central nervous system, particularly in the presence of reduced renal function in preterm infants and children with renal failure. Term infants with normal renal function do not seem to be at substantial risk of developing aluminium toxicity from soy protein-based formulas. ${ }^{2,3,6}$

It is important for pediatricians to know that SIF is adapted to the nutritional needs of infants and SIF fed infants have a normal growth and development. The medical indications for soy are very limited, but the use of SIF is mostly for CMPA in Indonesia. Efforts should be made to increase breastfeeding rate and duration but SIF remains valid option for term born infants if breastfeeding is not possible and cow's milk formula is not tolerated. 


\section{Conclusion}

The use of Soy Infant Formula (SIF) are widely known for the treatment and management of Cow's Milk Protein Allergy (CMPA) but other than allergy, SIF has met nutritional needs for term born infants if breastfeeding is not possible and cow's milk formula is not tolerated. The debate about the safety issues on SIF is ranging from sexual development disorder, hypothyroidism and low immune system and its correlation to SIF levels of aluminium, phytate and isoflavone. However, recent studies showed that all of these were not proven and inconclusive. Medical indications of using SIF are limited to CMPA, galactosemia and primary lactase deficiency, but there is room for SIF utilization beyond allergies.

\section{Conflict of Interest}

Authors declared no conflict of interest regarding this article.

\section{Open Access}

This article is distributed under the terms of the Creative Commons Attribution 4.0 International Licence

(http://creativecommons.org/licenses/by/4.0/), which permits unrestricted use, distribution, and reproduction in any medium, provided you give appropriate credit to the original author(s) and the source, provide a link to the Creative Commons license, and indicate if changes were made.

\section{Reference}

1. Hill L. W. \& Stuart, H. C. A soy bean food preparation for feeding infants with milk idiosyncrasy. J. Am. Med. Assoc 1929;93:985. [Google Scholar]

2. Ikatan Dokter Indonesia (IDAI). Rekomendasi Diagnosis dan Tatalaksana Alergi Susu Sapi. Badan Penerbit Ikatan Dokter Anak Indonesia (2014): Jakarta

3. Vandenplas Y, Castrellon PG, Rivas R, Gutierrez CJ, Garcia LD, Jimenez JE, et al. Safety of soya-based infant formulas in children. $\mathrm{Br} J$ Nutr 2014;111:1340-60. [Google Scholar]

4. Koletzko S, Niggeman B, Arato A, Dias JA, Heuschkel R, Husby S, et al. Diagnostic Approach and Management of Cow's Milk Protein Allergy in Infants and Children: ESPGHAN GI Committee practical guidelines. J Pediatr Gastroenterol Nutr 2012;55:221-9. [Google Scholar]

5. Reynaldo A. Hegar B. Soy Infant and Extensively Hydrolyzed Formula as Therapeutic Formula for Cow's Milk Protein Allergy. The Indonesian Journal of Gastroenterology Hepatology and Digestive Endoscopy 2014;15(2):98-104. [Google Scholar]

6. Bhatia J, Greer F. Use of Soy Protein-Based Formulas in Infant Feeding. Pediatrics 2008;121:1062-8. [Google Scholar]

7. Nowak-Wegrzyn A, Sampson HA, Wood RA, Sicherer SH. Food protein-induced enterocolitis syndrome caused by solid food proteins. Pediatrics 2003;111(4 pt1):829-35. [Google Scholar]

8. Testa I, Salvatori C, Cara, G. Di , Latini A, Frati F, Troiani S, et al. Soy-Based Infant Formula: Are Phyto-oestrogens Still in Doubt. Frontiers in nutrition 2018 Nov;5:110. [Google Scholar]

9. Canadian Paediatric Society, Dietitians of Canada, Health Canada. Nutrition for Healthy Term Infants. 2005. Ottawa, ON: Minister of Public Works and Government Services.

10. Rossen L, Simon A, Herrck K. Types of Infant Formulas Consumed in United States. Clinical Pediatr 2016;55:278-85. [Google Scholar]

11. Badger T, Ronis M, Hakkak R, Rowlands C and Korouria S . The Health Consequences of Early Soy Consumption. J. Nutr 2002;132:559-65. [Google Scholar]

12. World Health Organization (WHO). Standard for Infant Formula and Formulas for Special Medical Purposes Intended for Infants. CODEX STAN 721981 Rev 2017.

13. Peraturan Badan Pengawas Obat dan Makanan Nomor 1 tahun 2018 tentang Pengawasan Pangan Olahan untuk keperluan gizi khusus. BPOM Republik Indonesia.

14. Agostoni C, Axelsson I, Goutlet O, Koletzko B, Mk F, Puntis J, et al. Soy Protein Infant Formula: a commentary by the ESPGHAN Committee on Nutrition. J Pediatr Gastroenterol Nutr 2006;42:35261. [Google Scholar]

15. Vandenplas Y, Greef, E. De, Devreker T, Hauser B. Soy Infant Formula: is it that bad. Acta Paediatrica 2011;100:162-66. [Google Scholar]

16. Andres A, Cleves MA, Bellando J, Pivik R, Case P, Badger T. Developmental status of 1-year-old infants fed human milk, cow-milk formula or soy-based 
formula. Pediatrics 2012;129:1134-40. [Google Scholar]

17. Quak S. and Tan S. Use of Soy-Protein formulas and soyfood for feeding infants and children in Asia. Am J Clin Nutr 1998;68:1444. [Google Scholar]
18. Vandenplas Y, Munasir Z, Hegar B, Kumarawati D, Suryawan A, Kadim M, et al. A perspective on partially hydrolyzed protein infant formula in nonexclusively breastfed infants. Korean journal of pediatrics 2019;62(5):149. [Google Scholar] 